\title{
Front line demonstrations to improve the productivity of linseed (Linum usitatissimum L.) in Banda district of Bundelkhhand region of Uttar Pradesh
}

\author{
Shyam Singh \\ Krishi Vigyan Kendra (B.U.A.\&T.), Banda (U.P.) India (Email: shyamsingh15350@gmail.com)
}

\begin{abstract}
Krishi Vigyan Kendra, Banda organized 79 clusters front line demonstrations during Rabi seasons of years 2017-18, 2018-19 and 2019-20 on Recommended Dose of Fertilizer (RDF) along with Line sowing technology and high yielding variety on farmers' fields in the six villages. The soil of this area was two kinds of black soils known as kabar and mar with pH range 6.8 to 7.8 , organic matter 0.23 to 0.47 per cent, available nitrogen and also phosphorus was found low, potash was medium and soil organic carbon was low in all the demonstration plots. Yield of linseed was recorded between 9.45to 15.3q per ha (average 13.65 $\mathrm{q} / \mathrm{ha}$ ) by adoption of improved package of practices as Recommended Dose of Fertilizer along with Line sowing and high yielding variety over existing farmers practices, an average increase of 22.89 per cent in grain yield was recorded during the study period due to improved package of practices. Average technology gap was $3.01 \mathrm{q} / \mathrm{ha}$, extension gap was $2.54 \mathrm{q} / \mathrm{ha}$ and averaged technology index was 18.07 per cent. The average net returns was recorded Rs. 41099/ha from demonstration compared to farmer's field was Rs. 32036/ha. The averaged BCR was also reported to be higher 3.25 compared to farmers' practice (2.99) it was due to Recommended Dose of Fertilizer along with Line sowing technology and high yielding variety.
\end{abstract}

Key Words : Linseed, Azad Alsi-1, Padmini, Yield, HI, FLD, RDF, B:C ratio, IBCR

View Point Article : Singh, Shyam (2021). Front line demonstrations to improve the productivity of linseed (Linum usitatissimum L.) in Banda district of Bundelkhhand region of Uttar Pradesh. Internat. J. agric. Sci., 17 (2) : 594-599, DOI:10.15740/HAS/IJAS/17.2/594-599. Copyright@ 2021: Hind Agri-Horticultural Society.

Article History : Received : 23.03.2021; Revised : 28.03.2021; Accepted : 05.04.2021 